\begin{tabular}{|c|c|}
\hline 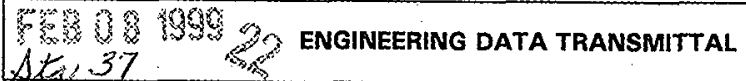 & 1. EDT 625825 \\
\hline
\end{tabular}

\begin{tabular}{|l|}
\hline 2. To: (Receiving Organization) \\
Tank Waste Remediation \\
\hline 5. Proj./Prog./Dept./Div: \\
Project W-314/Numatec \\
Hanford Corporation \\
\hline
\end{tabular}

8. originator Remarks:

For approval/release.

11. Receiver Remarks: 11A. Design Basel ine Document? [] Yes- [X] No

\author{
3. From: (originating organization) \\ Near Facility Monitoring \\ 6. Design Authority/ Design Agent/Cog. \\ Engr.: \\ R. M. Mitchel1
}

$\begin{array}{r}\text { 4. Related EDT No.: } \\ \text { NA } \\ \hline\end{array}$

7. Purchase order No.:

NA

\section{Equip./Component No.:} NA

10. System/Bldg./Facility; $\mathrm{NA}$

12. Major Assm. Dwg. No.:

NA

13. Permit/Permit Application No.: NA

14. Required Response Date: NA

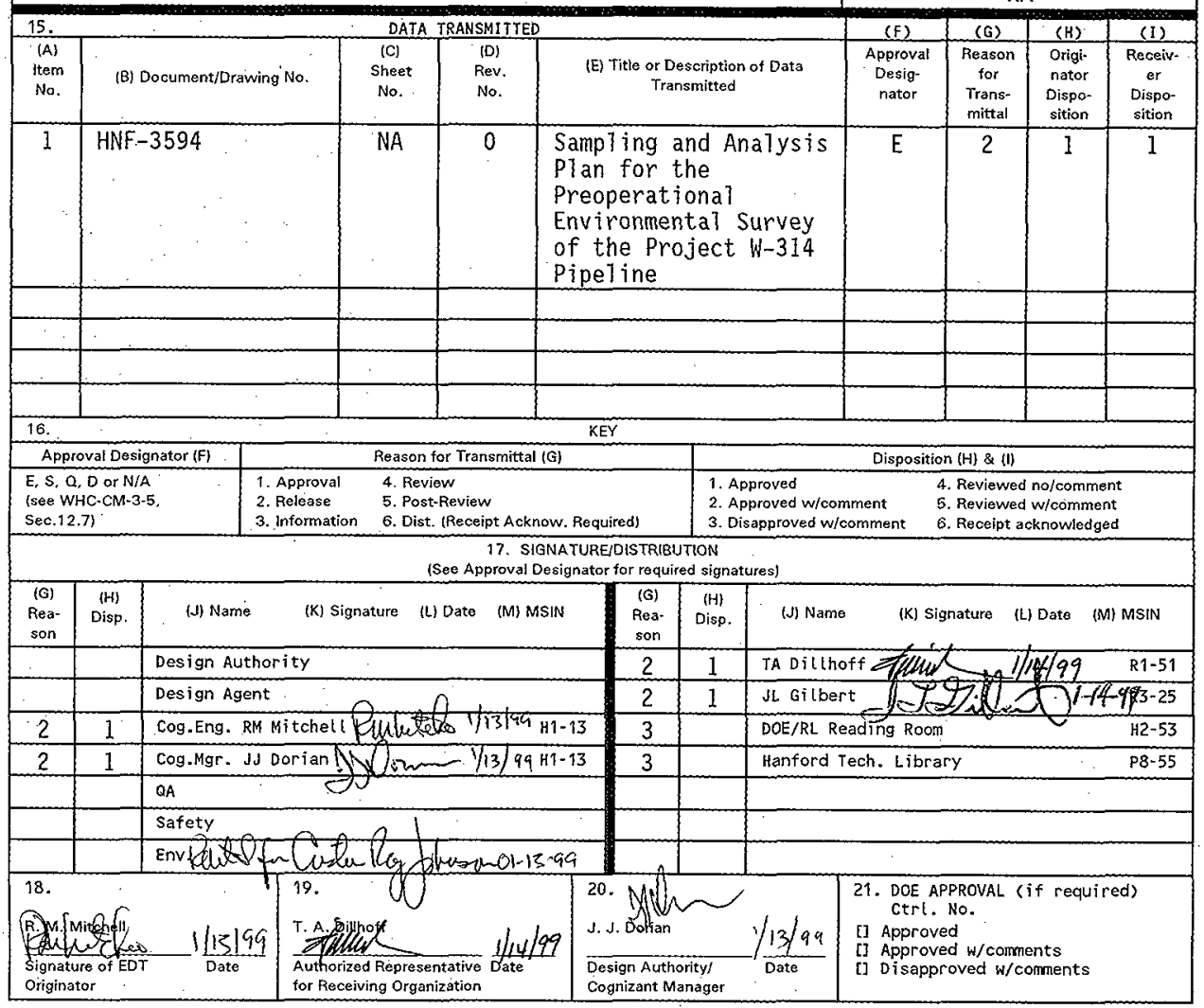




\title{
Sampling and Analysis Plan for the Preoperational Environmental Survey of the Project W-314 Pipeline
}

\author{
R. M. Mitche]1 \\ B. M. Markes \\ C. J. Perkins \\ Waste Management Federal Services, Inc., \\ Northwest Operations, Richland, WA 99352 \\ U.S. Department of Energy Contract DE-AC06-96RL13200

$\begin{array}{lll}\text { EDT/ECN: } & \text { EDT } 625825 & \text { UC: } 2070 \\ \text { Org Code: } & 7 B 200 & \text { Task order: GS080003 } \\ \text { CACN/COA: } 106055 / \text { CA20 } & \text { Project/Crosswa7k: 772029/103 } \\ \text { B\&R Code: } & & \text { Total Pages: 3031 cW/2-8-99 }\end{array}$

Key Words: Sampling Analysis, Characterization, Samples, W-314, Environmenta1, Preoperational

Abstract: This document provides a detailed description of the Sampling and Analysis Plan for the Preoperational Survey to be conducted for the W-314 Pipeline in the 200 East Area.

IRADEMARK DISCLAIMER. Reference herein to any specific commercial product, process, or service by trade name, tradenark, manufacturer, or otherwise, does not necessarily constitute or imply its endorsement, recommendation, or favoring by the United States Governinent or any agency thereof or its contractors or subcontractors.

Printed in the United States of America. To obtain copies of this document, contact: Document Control Services, P.O. Box 950, Mailstop H6-08, Richland WA 99352, Phone (509) 372-2420; Fax (509) 376-4989.
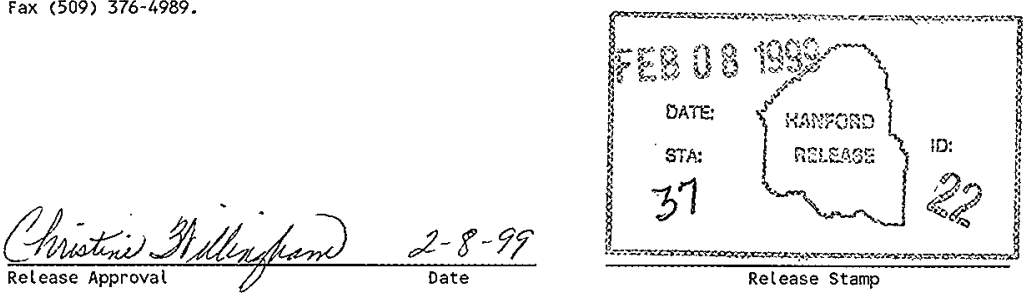
HNF-3594 Rev. 0

SAMPLING AND ANALYSIS PLAN FOR THE PREOPERATIONAL ENVIRONMENTAL SURVEY OF THE PROJECT W-314 PIPELINE

R. M. Mitcheil

B. M. Markes

C. J. Perkins

January 1999 


\section{CONTENTS}

1.0 INTRODUCTION $\ldots \ldots \ldots \ldots \ldots \ldots \ldots \ldots \ldots \ldots \ldots \ldots \ldots \ldots \ldots \ldots \ldots \ldots$

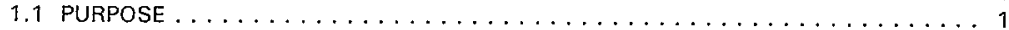

1.2 PROJECT BACKGROUND $\ldots \ldots \ldots \ldots \ldots \ldots \ldots \ldots \ldots \ldots \ldots \ldots \ldots$

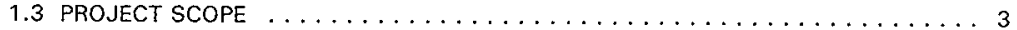

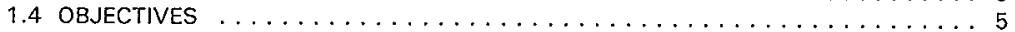

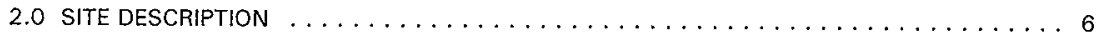

3.0 BACKGROUND ENVIRONMENTAL INFORMATION $\ldots \ldots \ldots \ldots \ldots \ldots \ldots$

3.1 ENVIRONMENTAL MONITORING $\ldots \ldots \ldots \ldots \ldots \ldots \ldots \ldots \ldots$

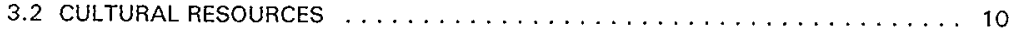

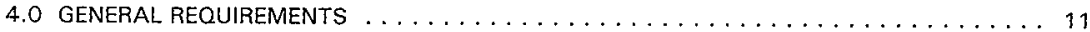

4.1 HANFORD GENERAL REQUIREMENTS $\ldots \ldots \ldots \ldots \ldots \ldots \ldots \ldots \ldots \ldots$

4.2 PROJECT $W$-314 PIPELINE GENERAL REQUIREMENTS $\ldots \ldots \ldots \ldots \ldots \ldots \ldots$

5.0 SAMPLING AND FIELD ACTIVITIES $\ldots \ldots \ldots \ldots \ldots \ldots \ldots \ldots \ldots$

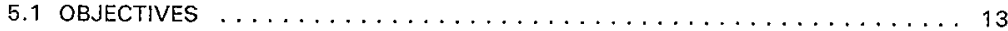

5.2 SAMPLE SITE SELECTION $\ldots \ldots \ldots \ldots \ldots \ldots \ldots \ldots \ldots \ldots \ldots \ldots \ldots \ldots$

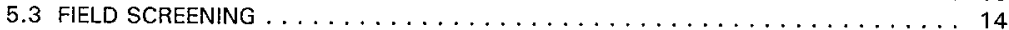

5.4 EQUIPMENT AND SUPPLIES $\ldots \ldots \ldots \ldots \ldots \ldots \ldots \ldots \ldots \ldots \ldots \ldots$

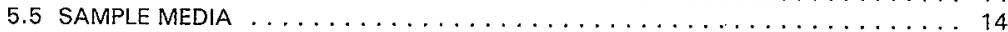

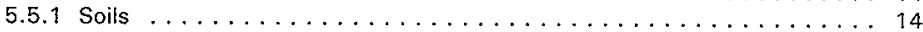

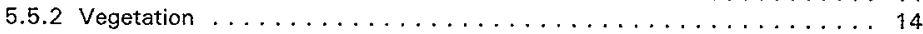

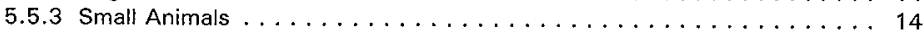

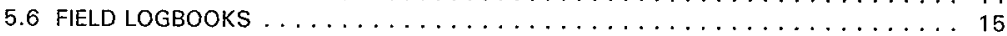

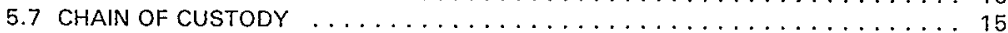

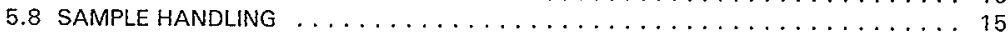

5.8 .1 Sample Labels . . . . . . . . . . . . . . . . . . 15

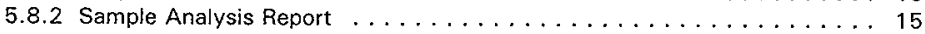

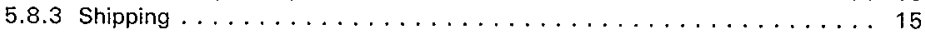

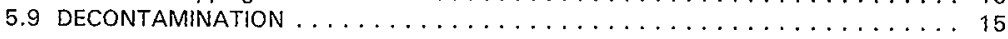

6.0 THERMOLUMINESCENT DOSIMETERS $\ldots \ldots \ldots \ldots \ldots \ldots \ldots \ldots$

7.0 AIR MONITORING $\ldots \ldots \ldots \ldots \ldots \ldots \ldots \ldots \ldots \ldots \ldots \ldots \ldots \ldots$

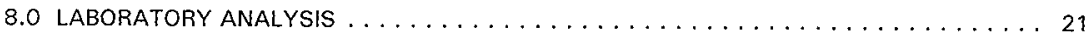

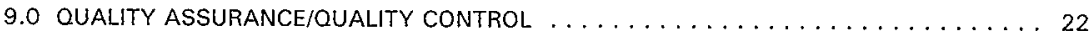

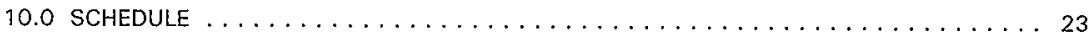

11.0 SAMPLING AND ANALYSIS PLAN MODIFICATIONS $\ldots \ldots \ldots \ldots \ldots \ldots \ldots$

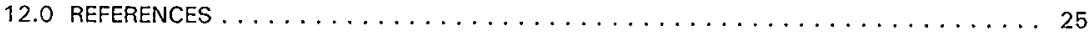




\section{LIST OF FIGURES}

1. Map of the Hanford Site and Location of the 200 East Area . . . . . . . . . . . . . . 2

2. Map of the 200 East Area Showing the Location of the Project W-314 Pipeline . . . . . . . 4

3. 200 East Soil Sampling Locations for Routine Monitoring . . . . . . . . . . . . . . 9

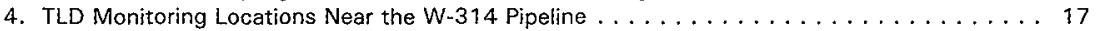

5. The 200 East Area Air Sampler Locations . . . . . . . . . . . . . . . . . . . . 19

\section{LIST OF TABLES}

1. Summary of Reported Soil Concentrations from Environmental Monitoring Sites Located

Proximal to the $\mathrm{W}-314$ Pipeline $(\mathrm{pCi} / \mathrm{g}) \ldots \ldots \ldots \ldots \ldots \ldots$

2. TLD Comparisons (Averages) for Locations 253, 254, 255, and 262 from 1996 and 1997

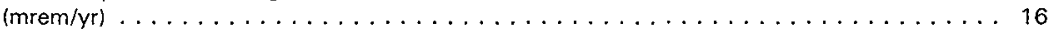

3. Ambient Air Monitoring Results - Five Year Averages $\left(\mathrm{pCi} / \mathrm{m}^{3}\right) \ldots \ldots \ldots \ldots$

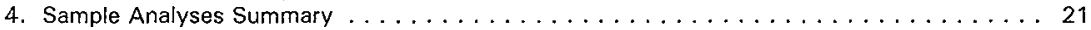

\section{LIST OF TERMS}

$\begin{array}{ll}\text { DCG } & \text { derived concentration guide } \\ \text { DOE } & \text { U.S. Department of Energy } \\ \text { EIS } & \text { Environmental Impact Statement } \\ \text { EMP } & \text { Environmental Monitoring Program } \\ \text { GDA } & \text { Grout Disposal Area } \\ \text { GPS } & \text { Global Positioning System } \\ \text { GTF } & \text { Grout Treatment Facility } \\ \text { HLW } & \text { high-level waste } \\ \text { ILAW } & \text { Immobilized Low Activity Waste } \\ \text { LLW } & \text { low-level waste } \\ \text { PHMC } & \text { Project Hanford Management Contract } \\ \text { PUREX } & \text { Plutonium-Uranium Extraction (Facility) } \\ \text { OA } & \text { quality assurance } \\ \text { QC } & \text { quality control } \\ \text { RHO } & \text { Rockwell Hanford Operations } \\ \text { ROD } & \text { Record of Decision } \\ \text { TLD } & \text { thermoluminescent dosimeter } \\ \text { TWRS } & \text { Tank Waste Remediation System } \\ \text { URM } & \text { Underground Radioactive Material } \\ \text { WDOH } & \text { Washington State Department of Health } \\ \text { WHC } & \text { Westinghouse Hanford Company } \\ \text { WMNW } & \text { Waste Management Federal Services, inc., Northwest Operations }\end{array}$


HNF-3594 Rev. 0

\section{SAMPLING AND ANALYSIS PLAN FOR THE PREOPERATIONAL. ENVIRONMENTAL SURVEY OF THE PROJECT W-314 PIPELINE}

\subsection{INTRODUCTION}

The U.S. Department of Energy (DOE) is the Federal agency responsible for waste management and environmental restoration at the Hanford Site near Richland, Washington (Figure 11. A major aspect of the waste management responsibility is the safe operation and containment of mixed radioactive and hazardous waste stored in 177 underground storage tanks. These include 149 single-shell tanks and 28 double-shell tanks that contain a total of 212 million L (56 million gal) of liquid, sludge, and saltcake.

The Tank Waste Remediation System (TWRS) Program was established in 1991 to treat, store, and dispose of the tank waste in a safe manner. To that end, a Final Environmental Impact Statement (EIS) (DOE 1996) and Record of Decision (ROD) (DOE 1997) were issued identifying the "preferred option" as tank waste vitrification and onsite disposal.

Phase 1 of this effort will embody a "proof of concept" phase for pretreatment and immobilization operations. This task has been designed for a private contractor to conduct this demonstration phase of the tank waste immobilization effort. The Project W-314 Pipeline will provide support for the waste feed delivery for the privatization immobilization effort (HNF-2500).

Preoperational monitoring efforts are necessary to determine existing environmental conditions, assess the potential for contaminants, and evaluate potential risks and hazards prior to construction and operation of new facilities in accordance with DOE Order 5484.1 (DOE 1981).

The primary purpose and need for conducting a preoperational survey is to establish an environmental baseline and identify potential risks to public health and safety, and to the environment. Specifically these risks include prevention of the release of radioactive materials into the air or to the soil surrounding the Project W-314. Pipeline, prevention of the potential migration of radionuclides through the soil column, reduction of occupational radiation exposure, and elimination of the risks to public and to workers from the deterioration of tank waste. This baseline will become the basis for determining the need for any modifications to the routine Environmental Monitoring Program (EMP).

DOE Order 5400.1, General Environmental Protection Program, requires an environmental study before the startup of new facilities and processes potentially impacting the environment. This DOE Order is expected to eventually become part of $10 \mathrm{CFR} 834$, Radiological Protection of the Public and the Environment.

\subsection{PURPOSE}

The sampling and monitoring efforts described herein will be conducted in support of an environmental baseline to establish the preoperational conditions for the Project W-314 Pipeline in accordance with the requirements set forth in DOE Order 5400.1, Chapter IV (DOE 1988a). The data obtained from the baseline sampling activities will be used to verify the following objectives:

- Identify baseline levels of contaminants in air, surface and subsurface (where necessary) soils, and vegetation, as well as levels of external radiation. 
Figure 1. Map of the Hanford Site and Location of the 200 East Area.

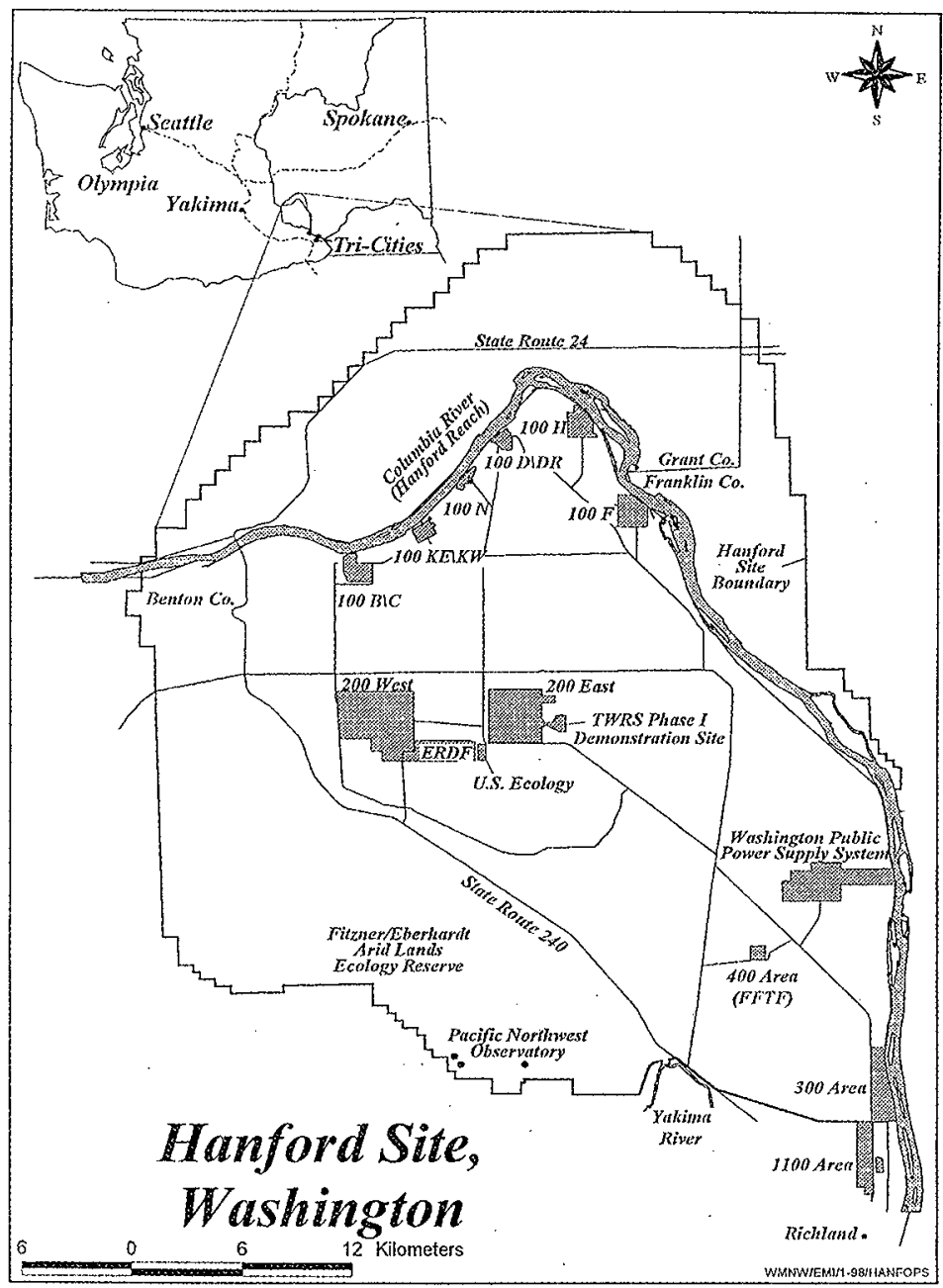


HNF-3594 Rev. 0

- Provide guidance for the development of personnel safety requirements during site development and operations.

- Allow for future determination of potential impacts to the environment from W-374 Pipeline construction and operational activities.

- Provide guidance for development of monitoring and surveillance requirements within, and surrounding, the W-314 Pipeline.

\subsection{PROJECT BACKGROUND}

The regulatory process conducted over the past few years to provide the direction for future actions regarding the tank wastes resulted in the issuance of the ROD (DOE 1997) with "Phased Implementation" as the preferred alternative.

The phased approach allowed for the retrieval and subsequent immobilization of the tank wastes through a Phase I demonstration effort lasting $\sim 10$ years and then using the information obtained to determine the best methodology for implementation of the full-scale production phase to last approximately 30 years.

One of the primary actions of the Phase I activities would be the construction of demonstration scale facilities to produce vitrified low-activity and high-activity waste for future disposal. It was determined that the pretreatment and immobilization operations for the low-level waste (LLW) and high-level waste (HLW) would be conducted by a private contractor. The produced immobilized low-activity waste (ILAW) would then be stored or disposed of in facilities developed by DOE and its contractors.

As part of the TWRS project, Project W-314 was developed to provide needed upgrades for waste transfer control and instrumentation, tank ventilation, and electrical distribution for existing tank farm facilities. The Project W-314 Pipeline will consist of three parallel pipelines placed aboveground, with routing principally outside the A Farm Complex (Figure 2). This portion of the pipeline is about $1,020 \mathrm{~m}(0.63 \mathrm{mi})$ long. The preoperational survey will be focused on these areas outside the Tank Farms. The lines will be covered and bermed using excess soil leftover from previous projects (Rasmussen et al. 1998 [HNF-2500]). The Project W-314 Pipeline (Figure 2) will allow for the upgrade of existing Double-Shell Tank (DST) System facilities to ensure the support of TWRS waste feed delivery requirements and continued safe management of tank waste (Popp et al. 1998 [HNF-3054]).

\subsection{PROJECT SCOPE}

Prior to the startup of new facilities or modification of existing facilities, DOE requires the development of environmental baseline surveys for the protection of workers, the public, and the surrounding environment. This regulatory guidance is provided as part of the General Environmental Protection Program, DOE Order 5400.1 (DOE 1988a); the Environmental Protection, Safety and Health Protection Information Reporting Requirements, DOE Order 5484.1 (DOE 1981); and Radiation Protection of the Public and the Environment, DOE 5400.5 (DOE 1990a). Additionally, since the ILAW product will be accepted by DOE and disposed of on the Hanford Site, it will be subject to DOE Order 5820.2A, Radioactive Waste Management (DOE 1988b). 
HNF-3594 Rev. 0

Figure 2. Map of the 200 East Area Showing the Location of the Project W-314 Pipeline.

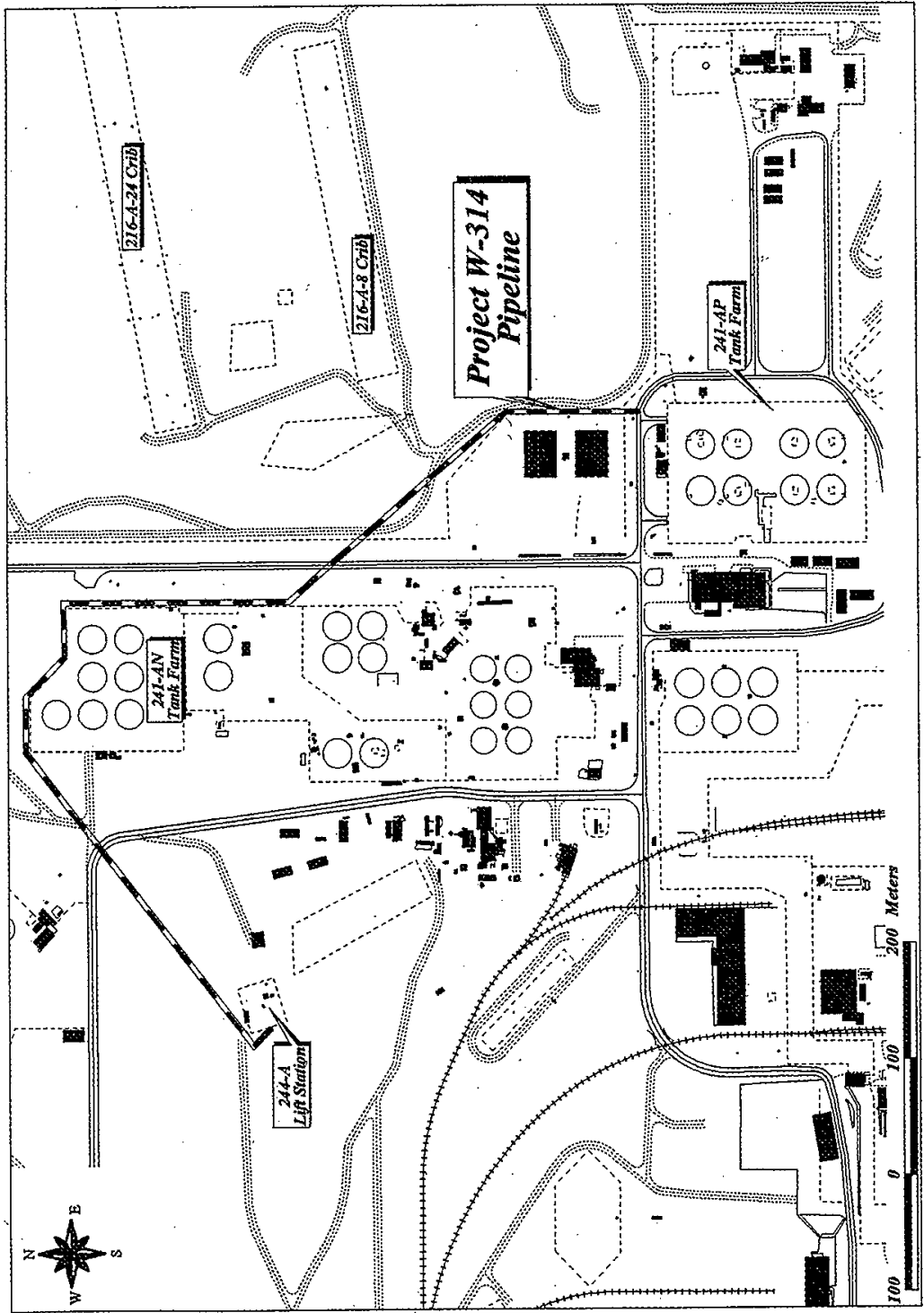


The technical guidance for implementation of baseline surveys is provided in DOE/EH-0173T, Environmental Regulatory Guide for Radiological Effluent Monitoring and Environmental Surveillance (DOE 1991) and in the handbook entitled, Environmental Monitoring for Low Level Waste Disposal Sites (DOE 1990b).

The proposed improvements provided by Project $W-314$ will increase the margin of safety and reliability for DST System operations and will assist the tank farms associated with waste feed delivery in achieving compliance with applicable environmental regulations. The subsequent goals of the $\mathrm{W}-314$ Project are to reduce health and safety risks to personnel and minimize exposure to radioactive and/or hazardous wastes (HNF-3054). Therefore, the focus of this preoperational survey is to determine the existing environmental conditions in, and around, the proposed pipeline route (Figure 2) for Project W-314.

\subsection{OBJECTIVES}

The primary objective of this preoperational survey is to establish an environmental baseline for the Project W-314 Pipeline. This will be done to determine the environmental conditions and establish background levels for contamination that may exist within the proposed site boundaries. This effort will provide documentation of the current levels of radioactive and selected chemical contaminants in the air, soils, vegetation, and small-mammal community at the site, as well as external radiation.

Specific concerns are related to the proximity of numerous Plutonium Uranium Extraction (PUREX) Facility cribs, Tank Farms, and other waste sites along the perimeter of the proposed pipeline route (Figure 2). Other concerns include prevailing winds which could transport contaminated dust particles from waste sites located upwind, as well as contaminated vegetation which could blow onto the site and scatter contaminated particles.

Elevated levels found during this preoperational survey, therefore, would be attributable to past practices and ongoing operations in the vicinity proximal to the location of the pipeline route. The information obtained will provide guidance for the determination of potential contaminant transport pathways. This information also will assist in the development of the operational monitoring and surveillance system for early detection of potential impacts from other facility operations, or from W-314 Pipeline construction and operations to the surrounding environment. 
HNF-3594 Rev. 0

\subsection{SITE DESCRIPTION}

The Project W-314 Pipeline will be located within and directly east of the 200 East Area (Figure 2). Positioned along its boundaries are a number of PUREX cribs (Figure 3). Located directly west of the site is the AP Tank Farm and the retired Grout Treatment Facility (GTF). The area is surrounded by a security fence and numerous roads crisscross the area providing access to wells, boreholes, and other facilities (Figure 2).

The 200 East Area lies on a plateau in the central portion of the Hanford Site (Figure 1) approximately $11 \mathrm{~km}$ south of the Columbia River. This site contains various radionuclide and hazardous waste process facilities and waste disposal facilities (e.g., liquid waste cribs and solid waste burial grounds). The ecology of the 200 Areas was originally mature shrub-steppe desert characterized by such vegetation as big sagebrush (Artemisia tridentata) and Sandberg's bluegrass (Poa sandbergin). Large tracts of these habitat types exist outside these areas. However, the sagebrush habitat within the areas has generally been disturbed. These disturbed areas support a variety of plants such as introduced bunchgrasses (Agropyron spp.), invaders such as Russian thistle (Salsola kalh), cheatgrass (Bromus tectorum), and rabbitbrush (Chrysothamnus spp.).

Animal species observed in the 200 Areas, while still similar to those found before human use of the area (except certain invaders which have taken advantage of the changed habitats), are generally at reduced numbers where there is a reductions in vegetative cover and species. Native species include the long-billed curlew (Numenius americanus), the horned lark (Eremiphila alpestris), the burrowing owl (Athene cunicularia), the sage sparrow (Amphispiza belli), the loggerhead shrike (Lanius ludovicianus), the Great Basin pocket mouse (Perognathus parvus), the deer mouse (Peromyscus maniculatus), the Western harvest mouse (Reithrodontomys megalotis), the pocket gopher (Thomomys talpoides) the black-tailed jackrabbit (Lepus californicus), the badger (Taxidea taxis), and the coyote (Canis latrans).

Non-native species taking advantage of the altered habitats include the domestic pigeon (Columba livia) and the house mouse (Mus musculus). Additional information on existing habitat and associated species can be found in Neitzel (1997).

Twelve plant species considered to be endangered, threatened, or sensitive by the Washington Natural Heritage Program (1994) are known to survive on or near the Hanford Site, seven of which are upland species (Sackschewsky et al. 1992). The upland species are northern wormwood (Artemisia campestris spp. Borealis var. wormskiodin) Hoover's desert parsley (Lomatium tuberosum), Piper's daisy (Erigeron piperianus), gray cryptantha (Cryptantha leucophea), Palouse milkvetch (Astragalus arrectus), and coyote tobacco (Nicotiana attenuata). Currently, none of the plant species are listed as federal threatened or endangered species. However, three local upland species are candidates for federal protection: (1) northern wormwood, (2) Hoover's desert parsley, and (3) Columbia milkvetch.

The bald eagle and peregrine falcon are the only federally listed threatened or endangered wildlife species occurring near the 200 Areas. Federal candidate species occurring near the 200 Areas include the ferrunginous hawk and loggerhead shrike. The pygmy rabbit, a shrub-steppe species listed as a federal candidate species and state threatened species, has not been observed on the Hanford Site since 1984 (Fitzner et al. 1992). The sage grouse, another federal candidate shrub-steppe species, has not been observed at the Hanford Site since the mid-1980's and probably no longer resides at the Site (Landeen et al. 1992). State listed threatened or endangered wildife include the peregrine falcon and ferruginous hawk. State candidate species observed near the. 200 Areas include the golden eagle, burrowing owl, sage thrasher, Swainson's hawk, striped whipsnake, Merriam's shrew, and sage sparrow (Stegen 1992). 
HNF-3594 Rev. 0

The specific areas comprising the proposed facilities are generally devoid of native vegetation, which over the years has been disturbed by various waste management activities, as well as construction of roads, buildings, storage basins, and other facilities. Thereby, the human activities and ongoing construction efforts have greatly reduced the likelihood that any protected species occur in the near vicinity. During the sampling activities, biologists will survey the area for any species of concern. 


\subsection{BACKGROUND ENVIRONMENTAL INFORMATION}

Environmental monitoring of radionuclide levels in the 200 East Area has been conducted by Rockwell Hanford Operations (RHO), Westinghouse Hanford Company (WHC), and Waste Management Federal Services, Inc., Northwest Operations (WMNW) in association with the burial grounds, liquid waste disposal facilities, and waste management activities conducted within and around these sites (Schmidt et al. 1990, 1992a, 1992b, 1993, 1994, 1995, 1996; Perkins et al. $1997,1998)$.

\subsection{ENVIRONMENTAL MONITORING}

Soil and vegetative sampling has been conducted on a routine basis in the 200 Areas for a number of years (see above). Samples are presently collected from each location on a biennial (every other year) basis, and the analytical data are reviewed, analyzed, and reported in the annual monitoring report. Figure 3 shows the location of the soil sampling sites in the 200 East Area.

Table 1 provides a summary of reported values in soils at four adjacent focations for selected radionuclides of concern from 1993 through 1997. Sample location D073, located near the Project W-314 corridor, has demonstrated elevated ${ }^{137} \mathrm{Cs}$ and ${ }^{90} \mathrm{Sr}$ concentrations during past sampling episodes.

Table 1. Summary of Reported Soil Concentrations from Environmental Monitoring Sites Located Proximal to the W-314 Pipeline ( $\mathrm{pCl} / \mathrm{g}$ ).

\begin{tabular}{|c|c|c|c|c|c|}
\hline \multirow{2}{*}{ Analyte } & \multicolumn{5}{|c|}{ Site location } \\
\hline & Year & $\mathrm{D} 067$ & D069 & 0073 & D074 \\
\hline${ }^{137} \mathrm{Cs}$ & 1997 & 0.2 & 0.04 & 1.1 & NC \\
\hline${ }^{0} \mathrm{Sr}$ & 1997 & 0.6 & 0.5 & 0.5 & $\mathrm{NC}$ \\
\hline $239 / 240 \mathrm{Pu}$ & 1997 & ND & ND & ND & $\mathrm{NC}$ \\
\hline${ }^{137} \mathrm{Cs}$ & 1996 & $\mathrm{NC}$ & $\mathrm{NC}$ & NC & 0.6 \\
\hline${ }^{90} \mathrm{Sr}$ & 1996 & $\mathrm{NC}$ & NC & NC & 0.09 \\
\hline $239 / 240 \mathrm{Pu}$ & 1996 & $\mathrm{NC}$ & NC & NC & 0.009 \\
\hline${ }^{137} \mathrm{Cs}$ & 1995 & 0.4 & 0.51 & 0.6 & NC \\
\hline${ }^{90} \mathrm{Sr}$ & 1995 & 1.0 & 0.3 & 3.0 & NC \\
\hline${ }^{239 / 240} \mathrm{Pu}$ & 1995 & 0.006 & 0.007 & 0.01 & NC \\
\hline${ }^{137} \mathrm{Cs}$ & 1994 & NC & NC & NC & 0.8 \\
\hline${ }^{90} \mathrm{Sr}$ & 1994 & NC & $\mathrm{NC}$ & $\mathrm{NC}$ & 0.2 \\
\hline${ }^{239 / 240} \mathrm{Pu}$ & 1994 & $\mathrm{NC}$ & $\mathrm{NC}$ & NC & 0.005 \\
\hline${ }^{137} \mathrm{Cs}$ & 1993 & 0.8 & 1.1 & 60.0 & 1.0 \\
\hline${ }^{90} \mathrm{Sr}$ & 1993 & 0.89 & 1.0 & 17.0 & 0.2 \\
\hline${ }^{239 / 240} \mathrm{Pu}$ & 1993 & 0.01 & 0.002 & 0.01 & 0.02 \\
\hline
\end{tabular}

$N C=$ Not collected.

ND $=$ Not detected 
HNF-3594 Rev. 0

Figure 3. 200 East Soil Sampling Locations for Routine Monitoring.

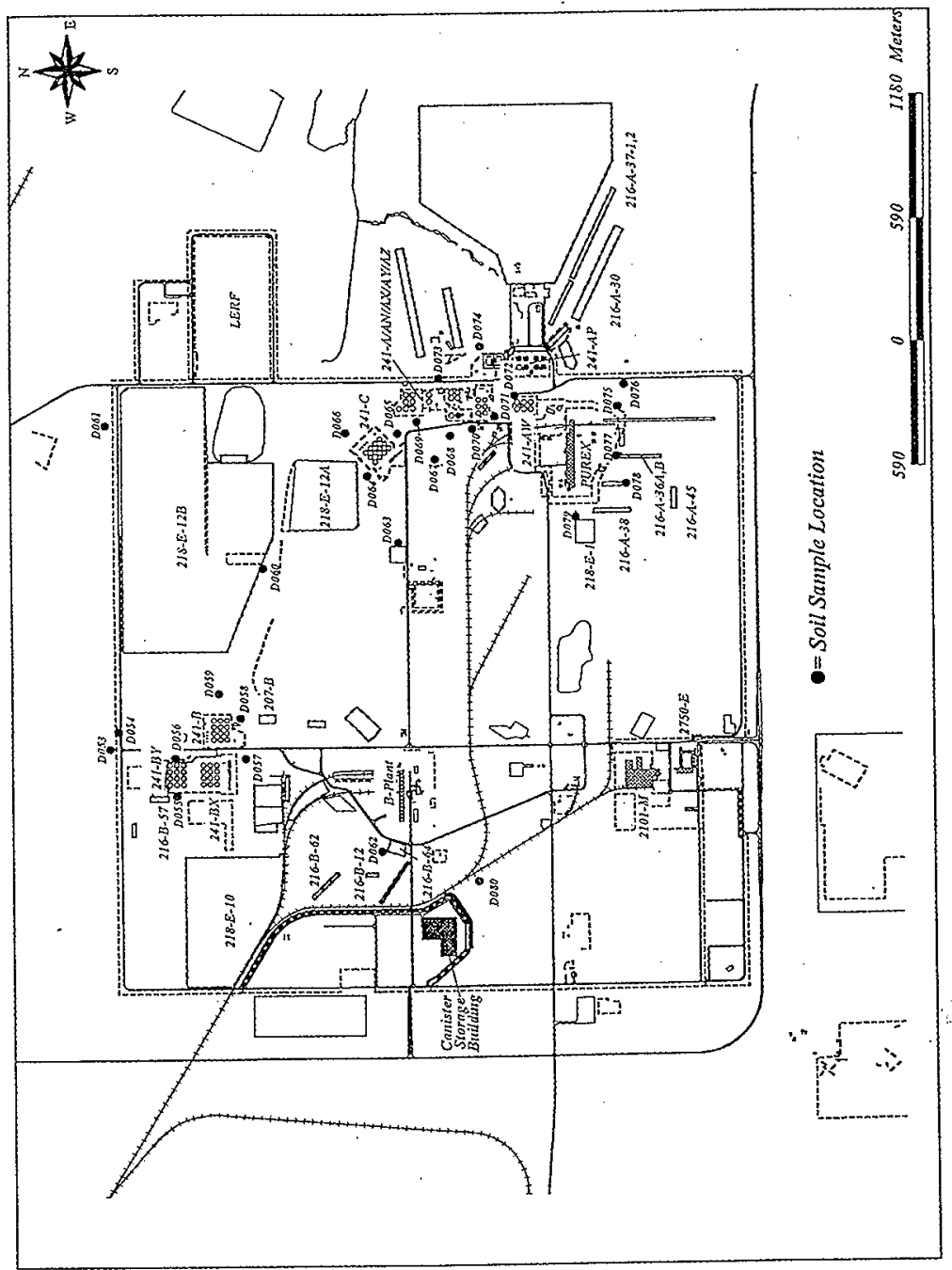


In summary, since the Project W-314 Pipeline will be constructed in largely disturbed areas located proximal to a number of waste sites and active facilities, the utilization of the previously developed historical data will allow for collection of a minimal number of additional samples in the appropriately selected media, as well as aid in the determination of "suspect" locations where samples could be taken. This determination is in concert with the recommendations of DOE Order 5400.1 to utilize existing data.

\subsection{CULTURAL RESOURCES}

The potential impacts of transporting, processing, and storing ILAW on a long-term basis have previously been reviewed (DOE 1996, DOE 1997). The W-314 Pipeline is primarily located inside or just outside the fenced portions of the site which have received extensive review (Chatters and Cadoret 1990). No known archaeological or historical sites are located within the proposed project site. However, sampling personnel will be informed to be on the lookout for any cultural resources and to notify the responsible personnel. 


\subsection{GENERAL REQUIREMENTS}

\subsection{HANFORD GENERAL REQUIREMENTS}

All personnel supporting this effort will have completed the applicable training and will perform work in accordance with the following:

- Operational Environmental Monitoring, WMNW-CM-004.

- Near-Facility Environmental Monitoring Quality Assurance Project Plan, HNF-EP-05383 (WMNW 1997).

- Environmental Training, HNF-PRO-459.

- Quality Assurance Program Plans, HNF-PRO-261.

- Safety and Environmental Reference Manual, WMNW-SERM-001.

- Site-specific health and safety plans, and Activity Hazard Analysis.

- Site-specific facility orientation.

\subsection{PROJECT $w$-314 PIPELINE GENERAL REQUIREMENTS}

The requirements and procedures applicable to the Project $W$-314 Pipeline field characterization activities are specified in the Sampling Services Procedures Manual, ES-SSPM-001. Applicable guidelines and procedures may include the following:

- SP 1-1, "Chain of Custody."

- SP 1-2, "Project and Sample Identification for Sampling Services."

- SP 1-3, "Control of Certificates of Analysis."

- SP 1-5, "Field Logbooks."

- SP 2-1, "Bottle Preservation."

- SP 2-5, "Laboratory Cleaning of Sampling Equipment."

- SP 2-6, "Sample Packaging and Shipping."

- SP 4-1, "Solid Sampling."

- SP 6-1, "Calibration and Control of Monitoring Instruments."

The field activities will conform to the requirements of a site-specific safety assessment to be completed before the initiation of sampling activities. A pre-job safety meeting, including any personnel associated with the field work, will be held before the performance of the sampling effort. Comments and concerns will be addressed and resolved at that time. 


\section{HNF-3594 Rev. 0}

An Activity Hazard Analysis Checklist will be developed for use by all parties involved in sampling activities or visiting the sample locations. A tailgate safety meeting will be held at the job site each day prior to commencement of operations. 


\subsection{SAMPLING AND FIELD ACTIVITIES}

Sampling efforts for the W-314 Pipeline will focus on the collection of environmental data and media which include surface soil, vegetation, thermoluminescent dosimeters (TLDs [external radiation]), and air. Historical information has been reviewed and evaluated to determine the types of samples needed, the analyses required for potential contaminants of concern, and prospective sample site selection.

\subsection{OBJECTIVES}

The primary objectives of the preoperational survey include the following: (1) determining current levels of radionuclides in environmental media attributable to previous and ongoing operations of other waste management facilities in the area; (2) providing data that will demonstrate the level of potential environmental impacts during Project $W-314$ construction and operations and, possibly, when corrective actions may be necessary; (3) characterizing existing levels of radionuclides in the selected media and other environmental pollutants for comparison of past and future trends for the enhancement of routine operational monitoring; and (4) identifying potential pathways for human exposure and environmental impacts.

\subsection{SAMPLE SITE SELECTION}

Before the initiation of sampling activities, a detailed map of the $W-314$ Pipeliine route has been obtained that shows the location of existing and proposed buildings, waste facilities, and other structures. The location of nearby waste sites, such as burial grounds, cribs, ditches, and ponds, also will be noted in the field logbook.

Sample locations will be selected from areas along the pipeline route where one or more of the following situations has been determined to exist:

- A radiation controlled area ( $R C A)$ which will be disturbed by W-314 Pipeline construction.

- Locations proximal to an RCA, or where the pipeline will be affected by "prevailing" or "high prevailing" winds.

- Areas where deep-rooted plants, such as tumbleweeds, have been associated with sub-surface contamination.

- Contaminated underground pipelines crossing the proposed route.

- Areas where the pipeline gradient will require the excavation of surface soils to a depth of $2 \mathrm{ft}$ or greater.

Using this information, the sites will be reconnoitered to determine the prime areas for the location of sampling points. Each sample site will be marked and noted on a map, which will be included in the field logbook, or final report.

All of the staked locations will be surveyed with a Trimble 4000 SSi 9 channel Global Positioning System (GPS) receiver and reduced to Washington State Plane (south zone) North American Datum of $1983 ; 1991$ adjustment in meters. 
HNF-3594 Rev. O

\subsection{FIELD SCREENING}

Field screening will be utilized to assist in the selection of samples to be submitted for laboratory analyses. Soils from potential sampling locations will be observed for discoloration, excessive moisture, or other anomalies. Any soils demonstrating these characteristics will be screened utilizing an organic vapor monitor and results recorded in the field logbook. Soil exhibiting positive readings for volatile organic constituents may be submitted for analyses. Collected samples will also be screened for radioactivity utilizing a Geiger-Muller counter and an alpha detector.

\subsection{EQUIPMENT AND SUPPLIES}

The following materials and equipment may be required to perform the outlined tasks:

- Plastic sampling jars.

- Glass sampling jars.

- Sample jars labels.

- Protection gloves.

- Ice chest with wet or "blue" ice.

- Absorbent (vermiculite) for shipping.

- Permanent marking pens.

- Safety glasses.

- Sampling devices (trowels, spoons, augers, shovels).

- Plastic sealer bags.

- Evidence tape.

- Measuring tape.

- Other items as needed.

\subsection{SAMPLE MEDIA}

\subsubsection{Soils}

Soil samples will be collected and preserved in accordance with the requirements outlined in SP 4-1, "Solid Sampling: Soil and Sediment Sampling."

\subsubsection{Vegetation}

Deep-rooted shrubs, and possibly grasses, will be collected in accordance with "Vegetation Sampling" (WMNW-CM-004).

\subsubsection{Small Animals}

The collection and preservation of small mammal samples will be conducted following the guidance provided in "Animal Sampling" (WMNW-CM-004). 


\subsection{FIELD LOGBOOKS}

Field activities will be recorded in a field logbook according to the protocols outline in SP 1-5, "Field Logbooks." Entries will be made in ink, signed, and dated, Photographs will be taken during sampling and to document any unusual circumstances encountered during the investigation.

\subsection{CHAIN OF CUSTODY}

Chain of custody records will be maintained in accordance with the requirements of SP 1-1, "Chain of Custody/Sample Analysis Request." The chain of custody form will establish the documentation necessary to ensure the traceability of the sample from time of collection until disposal.

\subsection{SAMPLE HANDLING}

Following collection, samples will be controlled in accordance with the requirements outlined in SP 2-6, "Sample Packaging and Shipping." All samples will be labeled, sealed, and placed in a container for preservation on ice or other appropriate cooling medium.

\subsubsection{Sample Labels}

Each sample will be identified and labeled with a unique sample number. Numbers will be assigned in the field per SP 1-2, "Project and Sample identification for Sampling Services." The sample location and corresponding sample numbers will be documented in the field logbook.

\subsubsection{Sample Analysis Report}

An approved Project Hanford Management Contract (PHMC) laboratory will be used to conduct laboratory analyses. The request for appropriate analyses will be included on the sample analysis request form as provided in SP 1-1, "Chain of Custody/Sample Analysis Request." Laboratory specific forms may be utilized in lieu of the site form and will be made available by the laboratory.

\subsubsection{Shipping}

Shipping requirements will conform with SP 2-6, "Sampling Packaging and Shipping."

\subsection{DECONTAMINATION}

Hand-held equipment used for the direct collection of samples will have been previously cleaned in accordance with SP 2-5, "Laboratory Cleaning of Sample Equipment." 


\subsection{THERMOLUMINESCENT DOSIMETERS}

A network of TLDs is positioned in and around the 200 Areas to monitor dose rates from external radiation sources (primarily gamma rays). The environmental TLDs measure dose rates from all types of external radiation sources. These include cosmic radiation, naturally occurring radiation in air and soil, and fallout from nuclear weapons testing, as well as any contribution from the Hanford Site activities. These outside radiation sources cause an estimated $\pm 20 \%$ deviation in TLD analyses. The results are reported in units of millirems per year (mrem/yr).

The TLD measurements are taken to determine dose rates in the operations area environment. From these data, the contribution of the Hanford Site activities to the dose rates in these areas can be discerned.

The Hanford Site uses the Harshaw TLD system, which includes the Harshaw 8807 dosimeter and the Harshaw 8800 TLD reader. The TLD packaging, which uses an "O ring" seal, protects the TLDs from light, heat, moisture, and dirt. The TLDs are placed $1 \mathrm{~m}$ (approximately $3 \mathrm{ft}$ ) aboveground at each location. The TLDs are placed near active and inactive surface-water disposal sites and near facilities (tank farms, cribs, and the facility fence line). Changing conditions in the vicinity of the TLD sample locations, such as remediation activities, removal or storage of radioactive material, and tank farm operations may also cause fluctuations in TLD analyses over time. The TLDs are exchanged each calendar quarter.

Figure 4 shows the location for four TLD monitoring locations which are located proximal to the W-314 pipeline. Table 2 provides a summary of the values recorded for 1996 and 1997 . The average for all of the 200 Area TLDs in 1997 was 109 mrem/yr.

Additional TLDs may be located along the length of the W-314 Pipeline in accordance with the guidance provided in WMNW-CM-004.

Table 2. TLD Comparisons (Averages) for Locations 253, 254, 255, and 262 from 1996 and 1997 (mrem/yr).

\begin{tabular}{|c|c|c|c|}
\hline Site ID & 1996 & 1997 & Percent Change \\
\hline 253 & 120 & 100 & $-17 \%$ \\
\hline 254 & 200 & 150 & $-25 \%$ \\
\hline 255 & 160 & 130 & $-15 \%$ \\
\hline 262 & 84 & 80 & $-5 \%$ \\
\hline
\end{tabular}


HNF-3594 Rev. 0

Figure 4. TLD Monitoring Locations Near the W-314 Pipeline.

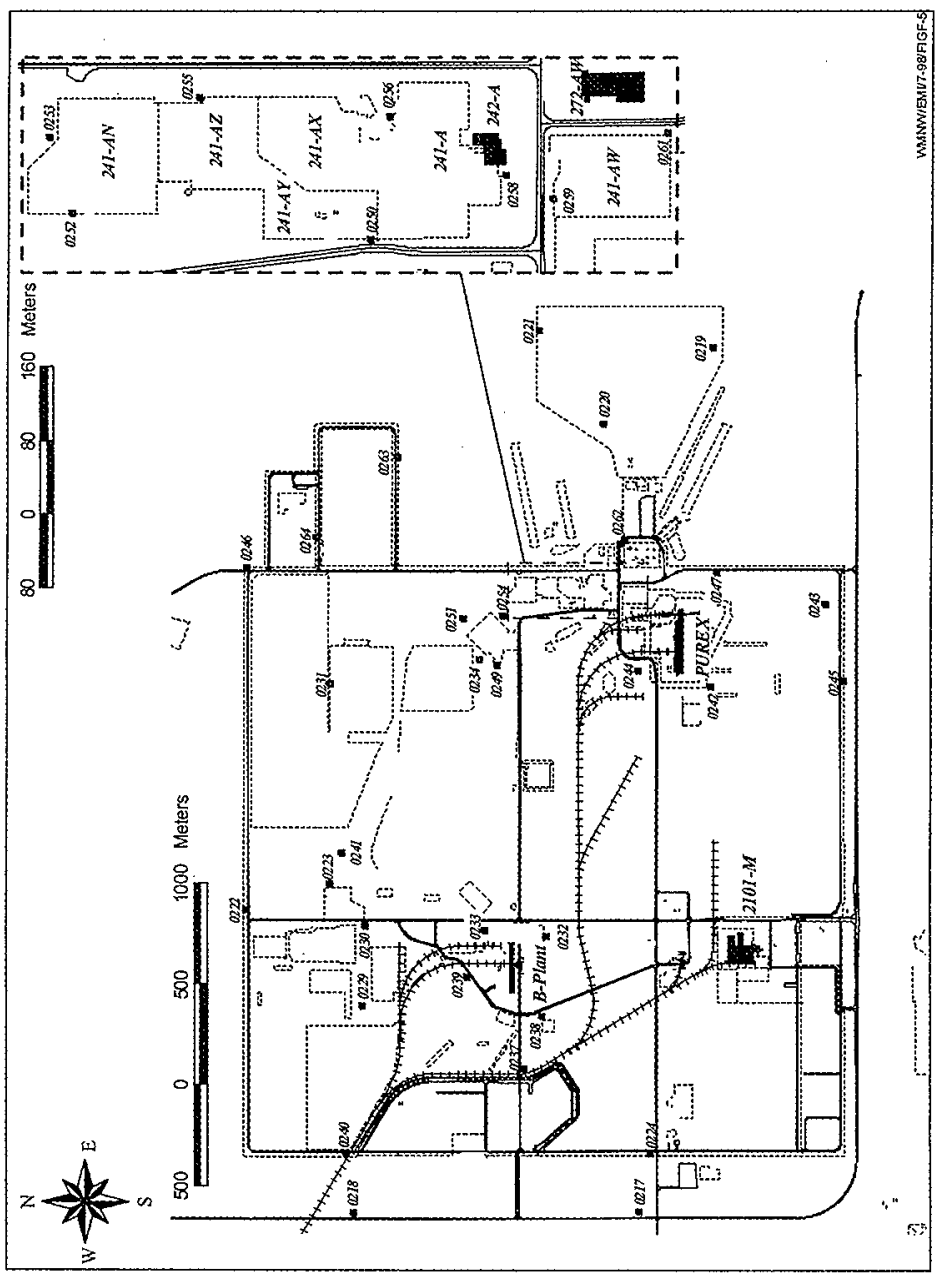




\subsection{AIR MONITORING}

Ambient air monitoring is conducted to determine baseline concentrations of radionuclides in the operations areas, to assess the impact of operations on the local environment, and to monitor diffuse emissions from sources located within the operations area. These measurements also provide an indication of facility and/or project performance and are used to demonstrate compliance with environmental protection criteria.

The placement of air monitoring stations takes into consideration potential source terms as well as prevailing wind direction. Meteorological conditions are monitored continuously by Pacific Northwest meteorology stations, which are strategically positioned in and around the Hanford Site.

Hanford Site air samplers operate at a flow rate of $0.056 \mathrm{~m}^{3} / \mathrm{min}\left(2 \mathrm{ft}^{3} / \mathrm{min}\right)$, drawing a sample through a $47 \mathrm{~mm}$ ( $2 \mathrm{in}$.), open-faced filter about $2 \mathrm{~m}(6 \mathrm{ft}$ ) aboveground. Typically, sample filters are exchanged biweekly, held one week (to allow for decay of the short-lived natural radioactivity), and then sent to the analytical laboratory for initial analysis of total alpha and total beta activity. These initial analyses serve as an indicator of potential environmental problems.

The filters are stored until the end of the six month sampling period, then segregated and composited by sample location (or as deemed appropriate) for specific radionuclide analysis. Segregating and compositing air filters by site provides a larger sample size and, thus, a more sensitive and accurate measurement of the concentration of airborne radionuclides.

To help assess the impact of Site operations, monitoring results are compared to DOE derived concentration guides (DCG), to the results obtained from the distant communities of Yakima and Sunnyside (reported by the Hanford Site Environmental Surveillance Program) and to data acquired from distant station N-981 located at the Wye Barricade.

Figure 5 shows the locations of the ambient air samplers in the 200 East Area. When compared to historical, prevailing wind directions, three existing sampling stations are situated such that most of the time they are downwind of the site (samplers N-158, N-984, and N-985), while two other existing stations are situated such that most of the time they are upwind of the site (samplers $\mathrm{N}-970$ and $\mathrm{N}-976$ ).

Table 3 provides five-year summaries (1993 through 1997) of radioanalytical data collected from the five nearby samplers and from the distant communities' sampling stations (1992 through 1996 ), as well as the corresponding DCG for each radionuclide. The analytical results for ${ }^{60} \mathrm{Co}$ and

${ }^{238} \mathrm{Pu}$ for all locations frequently exhibit statistical uncertainties above $100 \%$ and/or average concentrations less than zero; both of these indicate that the radionuclide is often below its analytical detection level. All other radionuclides shown in Table 3 are frequently detected with downwind sampler $\mathrm{N}-984$ often exhibiting the highest radionuclide concentrations for ${ }^{90} \mathrm{Sr},{ }^{137} \mathrm{Cs}$, ${ }^{234} \mathrm{U}$, and ${ }^{235} \mathrm{U}$. Since many of the analytical results indicate values that are at or near background, and/or analytical detection limits, it is not surprising that the highest concentrations of ${ }^{60} \mathrm{Co},{ }^{238} \mathrm{U}$, and ${ }^{238} \mathrm{Pu}$ are found at the distant community locations.

The available data are adequate to be used to establish the "background" concentrations of radionuclides in air in the vicinity of this project. Therefore, we believe the existing network of environmental air samplers is adequate to assess the impact of construction and operation of the W-314 Pipeline. 
Figure 5. The 200 East Area Air Sampler Locations.

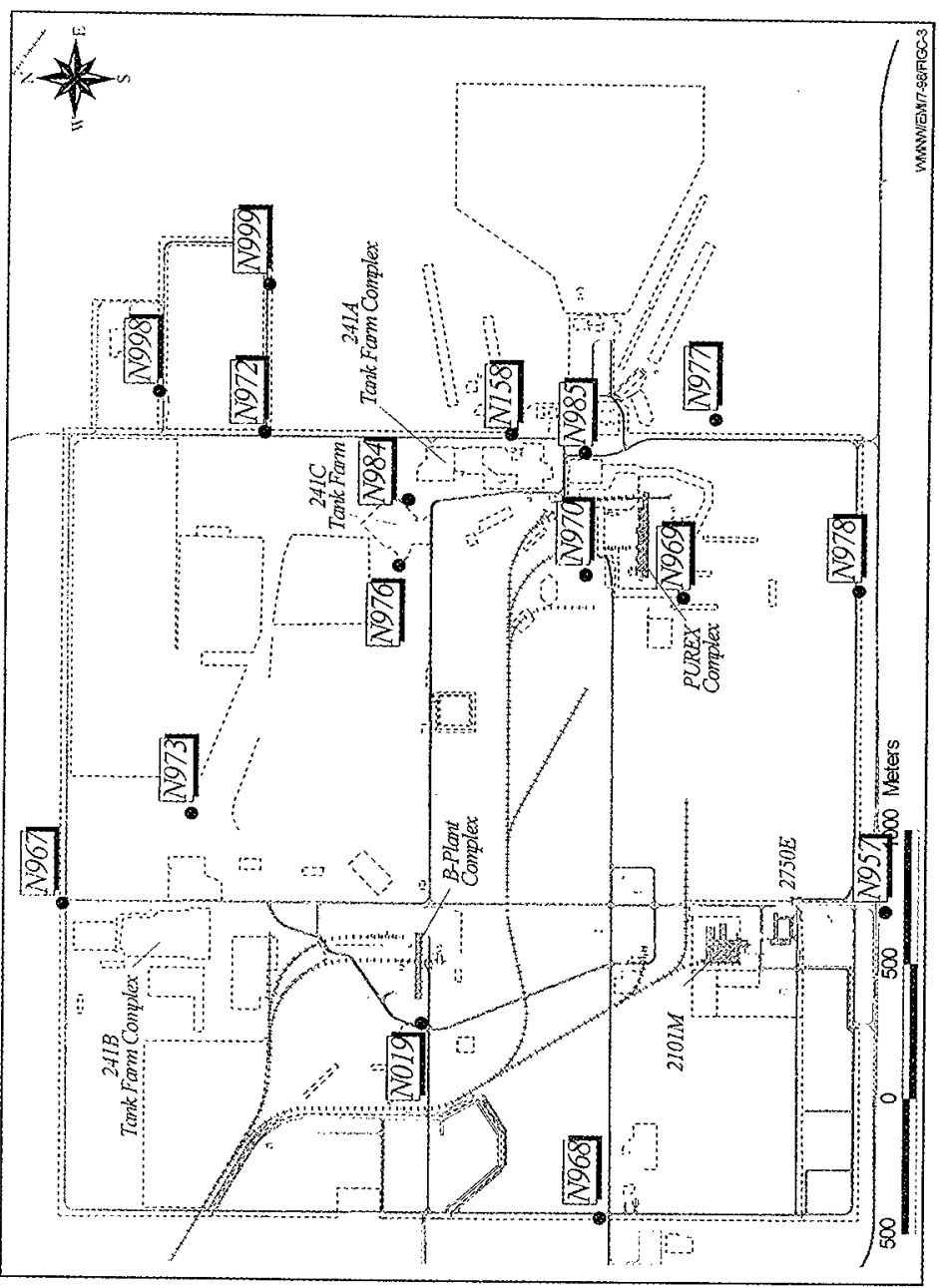


HNF-3594 Rev. 0

Table 3. Ambient Air Monitoring Results - Five Year Averages $\left(\mathrm{pCi} / \mathrm{m}^{3}\right)$.

\begin{tabular}{|c|c|c|c|c|c|c|c|}
\hline $\begin{array}{l}\text { Radio- } \\
\text { nuclide }\end{array}$ & $N-158$ & N-970 & $\mathrm{N}-976$ & $N-984$ & $N-985$ & $\begin{array}{c}\text { Distant } \\
\text { Community }\end{array}$ & DCG \\
\hline${ }^{\infty} \mathrm{Co}$ & $-1.2 \mathrm{E}-04 \pm 152 \%$ & $-9.4 E-05 \pm 225 \%$ & 2.7 E- $05 \pm 171 \%$ & $-1.2 \mathrm{E}-05 \pm>999 \%$ & $-1.6 \mathrm{E}-04 \pm 235 \%$ & $5.9 \mathrm{E}-05 \pm 110 \%$ & $8.00 E+01$ \\
\hline${ }^{90} \mathrm{Sr}$ & $2.5 \mathrm{E}-04 \pm 55 \%$ & 3.0 E- $04 \pm 39 \%$ & $4.0 \mathrm{E}-04 \pm 51 \%$ & 4.8 E $-04 \pm 33 \%$ & $1.3 \mathrm{E}-04 \pm 90 \%$ & $-5.0 \mathrm{E}-06 \pm 240 \%$ & $9.00 E+00$ \\
\hline${ }^{137} \mathrm{Cs}$ & $3.2 E-04 \pm 65 \%$ & $-1.9 \mathrm{E}-03 \pm 128 \%$ & $2.0 \mathrm{E}-05 \pm 128 \%$ & $4.2 \mathrm{E}-04 \pm 42 \%$ & 2.1 E- $04 \pm 57 \%$ & 1.7 E $-05 \pm 329 \%$ & $4.00 \mathrm{E}+02$ \\
\hline${ }^{239} \mathrm{U}$ & $1.5 \mathrm{E}-05 \pm 56 \%$ & $1.4 \mathrm{E}-05 \pm 82 \%$ & $2.2 E-05 \pm 47 \%$ & $2.5 \mathrm{E}-05 \pm 55 \%$ & 1.7 E.05 $0549 \%$ & $2.3 \mathrm{E}-05 \pm 16 \%$ & 9.00 E-02 \\
\hline${ }^{235} \mathrm{U}$ & 9.0 E-06 $188 \%$ & $6.1 \mathrm{E}-06 \pm 216 \%$ & $6.6 \mathrm{E}-06 \pm 254 \%$ & $2.1 \mathrm{E}-05 \pm 55 \%$ & $6.1 \quad E-06 \pm 97 \%$ & $2.0 \mathrm{E} .06 \pm 60 \%$ & 1.00 E-01 \\
\hline${ }^{238} \mathrm{U}$ & 2.0 E-0 $0 \pm 56 \%$ & $1.3 E-05 \pm 58 \%$ & $1.7 \varepsilon-05 \pm 46 \%$ & $2.0 \mathrm{E}-05 \pm 52 \%$ & $1.7 \mathrm{E}-05 \pm 49 \%$ & $3.5 \mathrm{E}-05 \pm 60 \%$ & $1.00 \mathrm{E}-01$ \\
\hline${ }^{238} \mathrm{Pu}$ & $-1.1 E-06 \pm 164 \%$ & $-2.1 E-07 \pm 637 \%$ & $2.0 E-07 \pm>999 \%$ & $-1.1 E-06 \pm 428 \%$ & $-1.2 E-06 \pm 206 \%$ & $3.2 \mathrm{E}-07 \pm 100 \%$ & $3.00 \mathrm{E}-02$ \\
\hline${ }^{239 / 240} \mathrm{Pu}$ & 3.7 E-06 $1181 \%$ & $4.1 E-06 \pm 78 \%$ & $3.4 \mathrm{E} .06 \pm 124 \%$ & $-1.8 E-06 \pm 157 \%$ & $3.8 \varepsilon-06 \pm 86 \%$ & $5.9 \mathrm{E}-07 \pm 78 \%$ & 2.00 E-02 \\
\hline
\end{tabular}

DCG $=$ Derived concentration guide . 


\subsection{LABORATORY ANALYSIS}

Procedure SP 2-1, "Bottle Preservation," provides general guidance for containers and preservation requirements. The contractor laboratory may request modifications to these recommendations as long as the quality of the data is not compromised. Sample containers are purchased precleaned from a supplier providing certification of internal laboratory procedures.

Samples collected for radionuclide analyses will be transported to the contract laboratory for processing. These samples will be analyzed for gamma spectroscopy to include ${ }^{241} \mathrm{Am}$. Additional analyses will include ${ }^{90} \mathrm{Sr}$, as well as isotopic plutonium and uranium.

The remaining samples will be transported to a contractor laboratory for analysis of metals, anions, and other analytes as requested. A complete list is provided in the sample analyses summary (Table 4).

Table 4. Sample Analyses Summary.

\begin{tabular}{|c|c|c|c|c|}
\hline Parameter/analysis & $\begin{array}{l}\text { Analytical } \\
\text { methods }\end{array}$ & Container/volume & Preservation & Holding time \\
\hline ICP metals & 6010 & \multirow{5}{*}{$\mathrm{G} 125 \mathrm{~mL}$} & \multirow{5}{*}{ Cool to $4{ }^{\circ} \mathrm{C}$} & 6 months \\
\hline Arsenic & 7060 & & & 6 months \\
\hline Lead & 6020 & & & 6 months \\
\hline Mercury & 7471 & & & 28 days \\
\hline Cyanide & 3353 & & & 14 days \\
\hline Anions & \multirow{3}{*}{ EPA 300.0} & \multirow{3}{*}{$P / G 250 \mathrm{~mL}$} & \multirow{3}{*}{ Cool to $4^{\circ} \mathrm{C}$} & \\
\hline $\mathrm{SO}_{4}, \mathrm{~F}, \mathrm{Cl}$ & & & & 28 days \\
\hline $\mathrm{NO}_{2}, \mathrm{NO}_{3}, \mathrm{PO}_{4}$ & & & & 48 hours \\
\hline Gamma scan & ITAS-RD-3219 & \multirow{5}{*}{$P / G 2000 \mathrm{~mL}$} & \multirow{5}{*}{ None } & \multirow{5}{*}{6 months } \\
\hline${ }^{90} \mathrm{Sr}$ & ITAS-RD-3204 & & & \\
\hline${ }^{241} \mathrm{Am},{ }^{24 i} \mathrm{Cm}$ & ITAS-RD-3220 & & & \\
\hline 238. 239/240 $\mathrm{Pu}$ & ITAS-RD-3209 & & & \\
\hline Isotopic uranium & ITAS-RD-4200 & & & \\
\hline
\end{tabular}

'Container types: $\mathrm{P}=$ plastic (polyethylene).

$\mathrm{G}=$ glass. 
HNF-3594 Rev. O

\subsection{QUALITY ASSURANCE/QUALITY CONTROL}

Quality assurance/quality control $(\mathrm{OA} / \mathrm{OC})$ samples are collected to provide for determination of field and laboratory QA/QC levels (HNF-EP-0538-3, WMNW 1997). Three types of (QA/QC) samples will be collected in the field:

- Duplicate samples will be collected from the same location, then submitted as two separate samples for separate analysis at the same laboratory.

- Split samples will be collected from the same locations, but will be sent to two different laboratories; one sample will be sent to the primary laboratory, the second will be sent to an independent laboratory.

- An equipment blank of clean silica sand will be submitted to verify the cleanliness of the decontaminated sampling equipment.

The number of $Q A / Q C$ samples required will conform to one each of the above designated samples collected/processed per 20 soil samples as a minimum. OA/OC samples required for vegetation will be limited to duplicate and split samples. Because of the uniqueness of the media, small mammals will not be submitted for $Q A / Q C$ purposes.

Personnel from the Washington State Department of Health (WDOH) (Office of Radiation Protection) may collect split samples of soil and vegetation. In order to reduce costs, the samples sent to the WDOH laboratory can be considered to represent the split samples described above. 


\subsection{SCHEDULE}

Sampling of the multiplicity of media identified will require a coordination of the efforts, depending on growth patterns of vegetation, animal activity, and availability of the media. If field conditions permit, it would be preferable to sample all the required media at the site over a three to five day period. That synchronization of effort will be the goal of the sample scheduling of this project. However, if environmental conditions are not favorable, sampling may take place over several days, or weeks as necessary.

In order to meet the requirements of DOE 5400.1 to include seasonal variability, additional samples may be collected from selected sample sites. These will allow comparisons with the radionuclide and metals data obtained previously. 


\subsection{SAMPLING AND ANALYSIS PLAN MODIFICATIONS}

Under field conditions, the optimal aspects of preliminary sample design are not always achievable. Factors influencing these efforts can be equipment malfunction or breakdown, weather conditions, improper equipment, soil conditions, physica! barriers to sampling equipment, and overly optimistic evaluation of capabilities. Because of unforeseen field conditions, modifications to the planned activity may be necessary as decided by the Field Team Leader.

To ensure efficient and timely completion of tasks, minor field changes can be made in the field by the person in charge of the particular activity. Minor field changes are those that have no adverse effects on the technical adequacy of the job or the work schedule. Such changes will be documented in the daily log books that are maintained in the field.

Major changes to this plan will be submitted on a Project Change Form. The change will require at least the verbal approval of the Field Team Leader and the project coordinator. The change will be filed, and a copy will be kept with the project file. 


\subsection{REFERENCES}

10 CFR 834, 1998, "Radiological Protection of the Public and the Environment," Code of Federal Regulations, as amended.

Chatters, J. C., and N. A. Cadoret, 1990, Archaeological Survey of the 200-East Area 200-West Area, Hanford Site, Washington, PNL-7264, Pacific Northwest Laboratory, Richland, Washington.

DOE, 1997, Record of Decision for the Tank Waste Remediation System, Hanford Site, Richland, Washington, 6450-01-P, U.S. Department of Energy, Washington, D.C.

DOE, 1996, Tank Waste Remediation System, Hanford Site, Final Environmental Impact Statement, DOE/EIS-0189, U.S. Department of Energy, Washington, D.C.

DOE, 1991, Environmental Regulatory Guide for Radiological Effluent Monitoring and Environmental Surveillance, DOE/EH-0173T, U.S. Department of Energy, Washington, D.C.

DOE, 1990a, Radiation Protection of the Public and the Environment, DOE Order 5400.5, U.S. Department of Energy, Washington, D.C.

DOE, 1990b, Low Level Waste Management Handbook Series: Environmental Monitoring for. Low Level Waste Disposal Sites, DOE-LLW-13Tg, Rev. 2, Washington, D.C.

DOE, 1988a, General Environmental Protection Program, DOE Order 5400.1, U.S. Department of Energy, Washington, D.C.

DOE, 1988b, Radioactive Waste Management, DOE Order 5820.2A, U.S. Department of Energy, Washington, D.C.

DOE, 1981, Environmental Protection, Safety, and Health Protection Information Reporting Requirements, DOE Order 5484.1, U.S. Department of Energy, Washington, D.C.

EPA, 1986, Test Methods for Evaluating Solid Waste, SW-846, Third Edition, EPA/Office of Solid Waste and Emergency Response, U.S. Environmental Protection Agency, Washington, D.C.

ES-SSPM-001, Sampling Services Procedures Manual, Waste Management Federal Services, inc., Northwest Operations, Richland, Washington.

Fitzner, R. E., S. G. Weiss, and J. A. Stegen, 1992, Biological Assessment for Threatened and Endangered Wildife Species, Related to CERCLA Characterization Activities, WHC-EP-0513, Westinghouse Hanford Company, Richland, Washington.

HNF-PRO-261, Quality Assurance Program Plans, Fluor Daniel Hanford, Inc., Richland, Washington.

HNF-PRO-459, Environmental Training, Fluor Daniel Hanford, inc., Richland, Washington.

Landeen, D. S., A. R. Johnson, and R. M. Mitchell, 1992, Status of Birds at the Hanford Site in Southeastern Washington, WHC-EP-0402, Rev. 1, Westinghouse Hanford Company, Richland, Washington. 
Mitchell, R. M., D. L. Edwards, B. M. Markes, R. K. Price, K. D. Reynolds, W. R. Thackaberry, C. J. Chou, V. G. Johnson, D. G. Horton, S. P. Reidel, K. A. Bergstrom, and T. H. Mitchell, 1998, TWRS Phase / Privatization Site Preconstruction Characterization Report, HNF-2067, Fluor Daniel Hanford, Richland, Washington.

Neitzel, D. A., 1997, Hanford Site National Environmental Policy Act (NEPA) Characterization, PNL-6415, Rev. 9, Pacific Northwest National Laboratory, Richland, Washington.

NRC, 1997, Multi-Agency Radiation Survey and Site Investigation Manual (MARSSM). NUREG-1575, (collaboratively developed by the U.S. Environmental Protection Agency, U.S. Department of Energy, U.S. Department of Defense, and U.S. Nuclear Regulatory Commission), Washington, D.C.

Perkins, C. J., A. R. Johnson, B. M. Markes, S. M. McKinney, and R. M. Mitchell , 1998, Hanford Site Near-Facility Environmental Monitoring Annual Report, Calendar Year 1997, HNF-EP-0573-6, Waste Management Federal Services, Inc., Northwest Operations for Fluor Daniel Hanford, inc., Richland, Washington.

Perkins, C. J., A. R. Johnson, B. M. Markes, S. M. McKinney, and R. M. Mitchell, 1997, Hanford Site Near-Facility Environmental Monitoring Annual Report, Calendar Year 1996, HNF-EP-0573-5, Waste Management Federal Services, Inc., Northwest Operations for Fluor Daniel Hanford, Inc., Richland, Washington.

Popp, 1. G., K. S. Tollefson, R. D. Potter, and R. L. Treat, 1998, Project W-314 Phase 1 Environmental Permits and Approvals Plan, HNF-3054, Lockheed Martin Hanford Corporation, Richland, Washington.

Rasmussen, O. R., 1. G. Popp, and J. D. Gaibraith, 1998, W-314 Waste Transfer Alternative Piping System Description, HNF-2500, Lockheed Martin Hanford Corporation, Richland, Washington.

Sackschewsky, M. R., D. S. Landeen, G. I. Baird, W. H. Richard, and J. L. Downs, 1992, Vascular Plants of the Hanford Site, WHC-EP-0554, Westinghouse Hanford Company, Richland, Washington.

Schmidt, J. W., J. W. Fassett, V. G. Johnson, R. M. Mitchell, B. M. Markes, S. M. McKinney, K. J. Moss, and C. J. Perkins, 1996, Westinghouse Hanford Company Operational Environmental Monitoring Annual Report, Calendar Year 1995, WHC-EP-0573-4, Westinghouse Hanford Company, Richland, Washington.

Schmidt, J. W., J. W. Fassett, A. R. Johnson, V. G. Johnson, B. M. Markes, S. M. McKinney, K. J. Moss, C. J. Perkins, and L. R. Richterich, 1995, Westinghouse Hanford Company Operational Environmental Monitoring Annual Report, Calendar Year 1994, WHC-EP-0573-3, Westinghouse Hanford Company, Richland, Washington.

Schmidt, J. W., A. R. Johnson, B. M. Markes, S. M. McKinney, and C. J. Perkins, 1994, Westinghouse Hanford Company Operational Environmental Monitoring Annual Report, Calendar Year 1993, WHC-EP-0573-2, Westinghouse Hanford Company, Richland, Washington.

Schmidt, J. W., A. R. Johnson, S. M. McKinney, and C. J. Perkins, 1993, Westinghouse Hanford Company Operational Environmental Monitoring Annual Report, Calendar Year 1992, WHC-EP-0573-1, Westinghouse Hanford Company, Richland, Washington. 
Schmidt, J. W., A. R. Johnson, S. M. McKinney, and C. R. Webb, 1992a, Westinghouse Hanford Company Environmental Surveillance Annual Report - 200/600 Areas, Calendar Year 1990, WHC-EP-0145-4, Westinghouse Hanford Company, Richland, Washington.

Schmidt, J. W., A. R. Johnson, S. M. McKinney, C. J. Perkins, and C. R. Webb, 1992b, Westinghouse Hanford Company Environmental Surveillance Annual Report - 200/600 Areas, Calendar Year 1991, WHC-EP-0573, Westinghouse Hanford Company, Richland, Washington.

Schmidt, J. W., C. R. Huckfeldt, A. R. Johnson, and S. M. McKinney, 1990, Westinghouse Hanford Company Environmental Surveillance Annual Report - 200/600 Areas, Calendar Year 1989, WHC-EP-0145-2, Westinghouse Hanford Company, Richland, Washington.

Shade, J. W., 1997, TWRS Retrieval Area Disposal Mission: Immobilized Low-Activity Waste Disposal Plan, HNF-1517, Fluor Daniel Hanford, Inc., Richland, Washington.

Shord, A. L., 1996, Tank Waste Remediation System Complex Site Evaluation Report, WHC-SD-WM-SE-021. Westinghouse Hanford Company, Richland, Washington.

Stegen, J. A., 1992, Biological Assessment for State Candidate and Monitor Wildife Species Related to CERCLA, WHC-SD-EN-EE-009, Westinghouse Hanford Company, Richland, Washington.

Swanson, L. C., D. C. Weeks, S. P. Luttrell, R. M. Mitchell, D. S. Landeen, A. R. Johnson, and R. C. Roos, 1988, Grout Treatment Facility Environmental Baseline and Site Characterization Report, WHC-EP-0150, Westinghouse Hanford Company, Richland, Washington.

Washington Natural Heritage Program, 1994, Endangered, Threatened, and Sensitive Vascular Plants of Washington, Washington State Department of Natural Resources, Olympia, Washington.

WMNW-CM-004, Operational Environmental Monitoring, Waste Management Federal Services, Inc., Northwest Operations, Richland, Washington.

WMNW-SERM-001, Safety and Environmental Reference Manual, Waste Management Federal Services, Inc., Northwest Operations, Richland, Washington.

WMNW, 1997, Near-Facility Environmental Monitoring Quality Assurance Project Plan, HNF-EP-0538-3, Waste Management Federal Services, Inc., Northwest Operations, Richland, Washington. 


\section{DISTRIBUTION SHEET}

\begin{tabular}{|c|c|c|c|c|c|}
\hline \multirow{2}{*}{$\begin{array}{l}\text { To } \\
\text { Distribution }\end{array}$} & \multirow{2}{*}{\multicolumn{3}{|c|}{$\begin{array}{l}\text { From } \\
\text { R. M. Mitche11 }\end{array}$}} & \multicolumn{2}{|l|}{ Page 1 of 1} \\
\hline & & & & \multicolumn{2}{|c|}{ Date Jan. 13, 1999} \\
\hline \multirow{2}{*}{\multicolumn{4}{|c|}{$\begin{array}{l}\text { Project Title/Work Order } \\
\text { Sampling and Analysis P1 an for the Preoperational Environmental } \\
\text { Survey of the Project W-314 Pipeline (HNF-3594, Rev. 0) }\end{array}$}} & \multirow{2}{*}{\multicolumn{2}{|c|}{$\begin{array}{ll}\text { EDT No. } & 625825 \\
\text { ECN No. } & \text { N/A } \\
\end{array}$}} \\
\hline & & & & & \\
\hline Name & MSIN & $\begin{array}{l}\text { Text } \\
\text { With All } \\
\text { Attach. }\end{array}$ & Text Only & $\begin{array}{l}\text { Attach./ } \\
\text { Appendix } \\
\text { Only }\end{array}$ & $\begin{array}{c}\text { EDT/ECN } \\
\text { Only }\end{array}$ \\
\hline $\begin{array}{l}\text { P. K. Brockman } \\
\text { L. P. Diediker } \\
\text { T. A. Dillhoff (3 copies) } \\
\text { J. J. Dorian } \\
\text { B. G. Erlandson } \\
\text { J. D. Galbraith } \\
\text { J. L. Gilbert } \\
\text { J. L. Homan } \\
\text { A. R. Johnson } \\
\text { B. M. Markes } \\
\text { R. M. Mitchel] (5 copies) } \\
\text { D. J. Moak } \\
\text { C. J. Perkins } \\
\text { K. W. Tollefson } \\
\text { Document Processing Center } \\
\text { RL Reading Room } \\
\text { Hanford Tech. Library }\end{array}$ & $\begin{array}{l}H 1-11 \\
H 6-36 \\
R 1-51 \\
H 1-13 \\
R 1-51 \\
\text { R3-73 } \\
\text { R3-25 } \\
\text { R3-25 } \\
H 1-13 \\
H 1-13 \\
H 1-13 \\
H 1-11 \\
H 1-13 \\
T 4-52 \\
\text { A3-94 } \\
H 2-53 \\
\text { P8-55 }\end{array}$ & 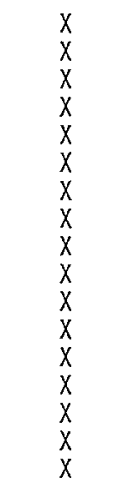 & & & \\
\hline Tentral Filea & $B /-07$ & $x$ & & & \\
\hline
\end{tabular}

